\title{
Gingival Rhabdomyosarcoma in an Adult: A Unique Entity
}

\author{
Bir Erişkin Dişeti Rabdomyosarkomu: Özgün Bir Antite
}

\author{
Priya SAHNi', Abhishek SiNGHVi', Meghanand T. NAYAK', Shakti Singh DEORA ${ }^{2}$ \\ 'Department of Oral \& Maxillofacial Pathology, Vyas Dental College \& Hospital, Jodhpur, RAJASTHAN, INDIA \\ ${ }^{2}$ Department of Oral \& Maxillofacial Surgery, Mathura Das Mathur Hospital, Jodhpur, RAJASTHAN, INDIA
}

\begin{abstract}
Rhabdomyosarcoma is a disease that predominantly affects children. Approximately 40 per cent are located in the head and neck region but it is rare in the oral cavity.

This article describes an interesting case of an embryonal rhabdomyosarcoma in a 36-year-old male, involving the mandibular gingiva. The lesion showed radiolucency with ill-defined margins that was crossing the midline. The history revealed a similar lesion six months back at the same site and the lesion had been completely excised. The biopsy reports confirmed the diagnosis of embryonal rhabdomyosarcoma after which en-bloc resection of the tumor was performed with administration of chemotherapy and radiotherapy.

Due to high recurrence rate of rhabdomyosarcomas in adults, multimodal therapy should be planned for proper care of the patient. Clinical, radiological, histopathological and management aspects are discussed here.
\end{abstract}

Key Words: Rhabdomyosarcoma, Embryonal, Gingiva, Adult

\section{ÖZ}

Esas olarak çocukluk çağının malign bir tümörü olan rabdomyosarkom olgularının yaklaşık \%40'ı baş boyun bölgesinde lokalize olmakla birlikte oral kavitede nadirdir.

$\mathrm{Bu}$ makalede, 36 yaşındaki erkek hastada mandibuler gingival yerleşimli embriyonel rabdomyosarkom olgusu sunulmuştur. Oral kavitede sınırları belirgin olmayan ve orta hattı geçen radyolusen kitle izlendi. Öyküsünden 6 ay önce aynı bölgeden benzer bir lezyonun eksize edildiği öğrenildi. Biyopsinin embriyonel rabdomyosarkom olarak raporlanmasını takiben en-blok rezeksiyon ve ardından kemoterapi ve radyoterapi uyguland.

Erişkin rabdomyosarkomlarının tekrarlama oranı yüksek olduğu için multimodal tedavi planı gereklidir. Makalede, rabdomyosarkomun klinik, radyolojik, histopatolojik bulguları ve tedavi yaklaşımı tartışılmıştır.

Anahtar Sözcükler: Rabdomyosarkom, Embriyonel, Dişeti, Erişkin

\section{INTRODUCTION}

Rhabdomyosarcoma (RMS) is a mesenchymal malignant neoplasm, first described by Weber in 1854, and accounts for $6 \%$ of all the malignancies in children under 15 years of age $(1,2)$. It exhibits skeletal muscle cells of varying differentiation degrees (3). Histopathology of RMS is analogous to myogenesis in the developing embryo, yielding clues to the biology of these lesions. For this reason, it is correct to define RMS as a tumor derived from primitive mesenchyme and exhibiting a profound tendency towards myogenesis than to define it as a cancer arising from skeletal muscle (4). This concept was eloquently expressed by Masson in 1970 who referred to RMS as "rhabdopoietic sarcomas," and this explains the observation that more tumors arise from viscera and axial soft tissues than from the extremities (5). The head and neck region and genitourinary tract are the most common sites for

(Turk Patoloji Derg 2015, 31:153-157)

Received : 10.10.2011 Accepted : 11.06.2012
RMS. In the head and neck region the commonly affected sites are the orbit, paranasal sinuses, and the neck (6). Oral RMS is rare, and when it occurs it is more frequent in the soft palate $(1,2)$.

The incidence of RMS appears to be higher in the AfricanAmerican and Caucasian population than Asians $(7,8)$. Two-third of RMS cases are diagnosed in children 2 to 15 years of age with a mean age of 6 years, and there is a small male predominance $(1,2,7)$. RMS is rare in adults, accounting for 2 to 5 per cent of adult soft tissue sarcomas and they show different biological behavior compared to children with tumors that are more aggressive and have an overall worse survival rate $(9,10,11)$.

Histologically, embryonal RMS is characterized by zones of loose and dense cellularity, remarkably recapitulate normal embryonal myogenesis, in which loose primitive mesenchyme condenses to form nascent muscle (12).

Correspondence: Priya SAHNI

Vyas Dental College \& Hospital, Department of Oral \& Maxillofacial

Pathology, Jodhpur, RAJASTHAN, INDIA

E-mail: priyajodhpur@yahoo.com Phone: +91941 4095323 
In this article, we describe an unusual case of gingival embryonal RMS occurring in an adult where the diagnosis was made only by means of histopathology and immunohistochemistry.

\section{CASE REPORT}

A 36-year-old male was referred for evaluation of a symptomatic lesion in the anterior right mandibular region. The clinical examination of the patient revealed a painless mass, firm in consistency, measuring about $8 \times 5 \mathrm{~cm}$ on the mandibular right second molar region and crossing the midline, to involve the mandibular left anterior region. The borders were ill-defined and the mucosa covering the lesion was reddish in color with spontaneous bleeding on palpation (Figure 1). The patient had noticed a similar

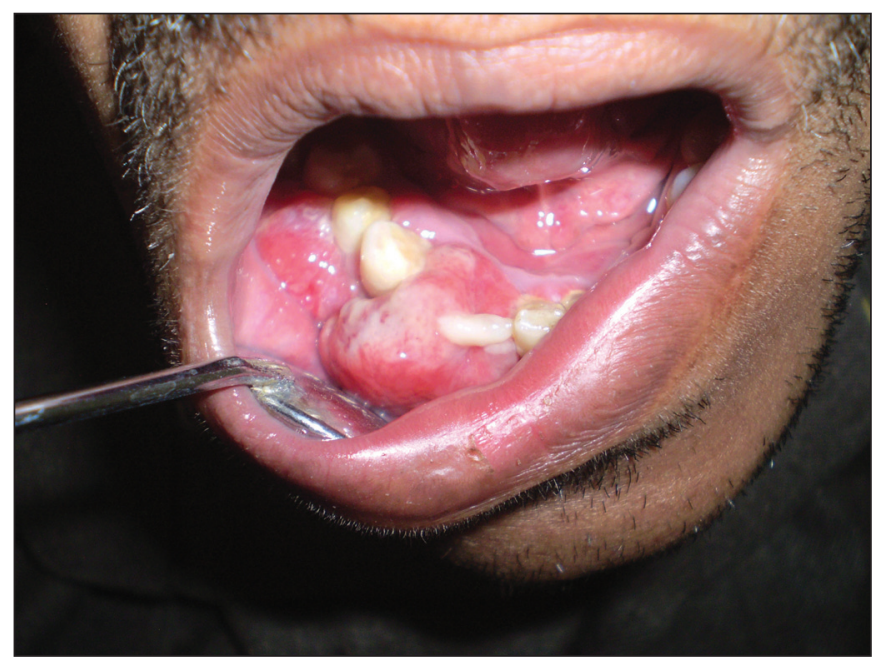

Figure 1: Intra-oral examination reveals an irregular mass involving the right mandibular gingiva and alveolar mucosa with obliteration of the buccal vestibule.

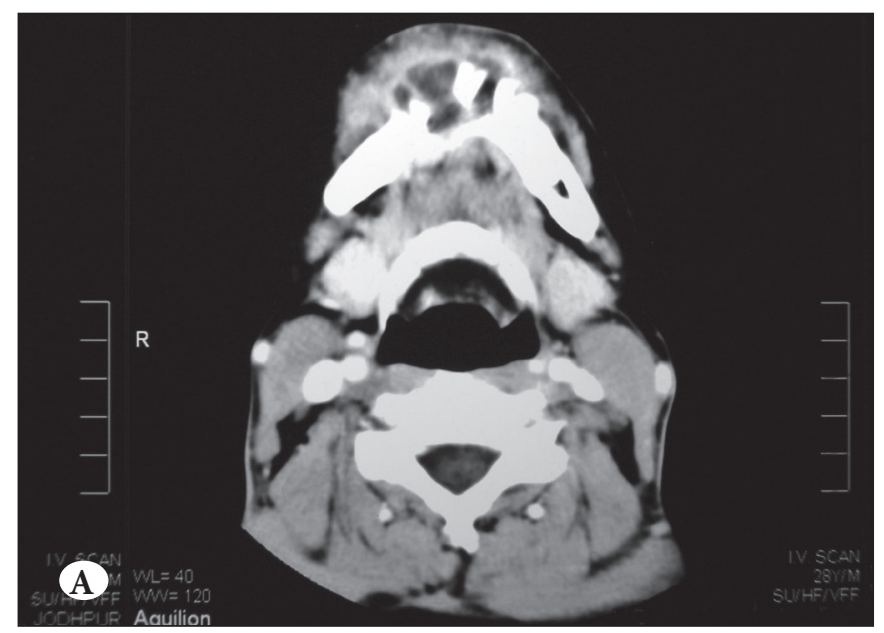

lesion six months back at the present site and had undergone complete excision of the lesion. A histopathological diagnosis of embryonal RMS was made. However, the lesion recurred and grew rapidly to the presenting size.

OPG and CT scan study showed an expansile, osteolytic lesion involving the right inferior alveolus and body of the mandible (Figure 2A). An extraosseous soft tissue component was noticed both anterior and posterior to the mandible (Figure 2B). Loss of the right mandibular lateral incisor with loosening of other teeth was noticed in the right mandibular quadrant (Figure 3). No significant cervical lymphadenopathy was noticed.

An incisional biopsy was performed and the specimen was referred for histopathological examination. Under light microscopic examination, the tumor was observed to be composed of dense cellular connective tissue stroma. Cells were round to oval with hyperchromatic nuclei, frequent mitotic figures and indistinct cytoplasm (Figure 4). The pathology evaluation showed embryonal RMS that was verified by a immunohistochemistry panel. The immunohistochemical tests were performed with antibodies against desmin, myogenin and myoglobin. Among these markers, desmin and myogenin revealed strong positive staining whereas immunoreactivity to myoglobin was not detected (Figure 5, 6).

Following the histological diagnosis, en bloc resection of the tumor with a wide margin of normal tissue was performed (Figure 7). After removal of the lesion, a pectoralis myocutaneous graft was placed along with an arch bar. An excisional biopsy process was performed and revealed findings similar to the incisional biopsy. Subsequent to surgery, the patient underwent chemotherapy with a

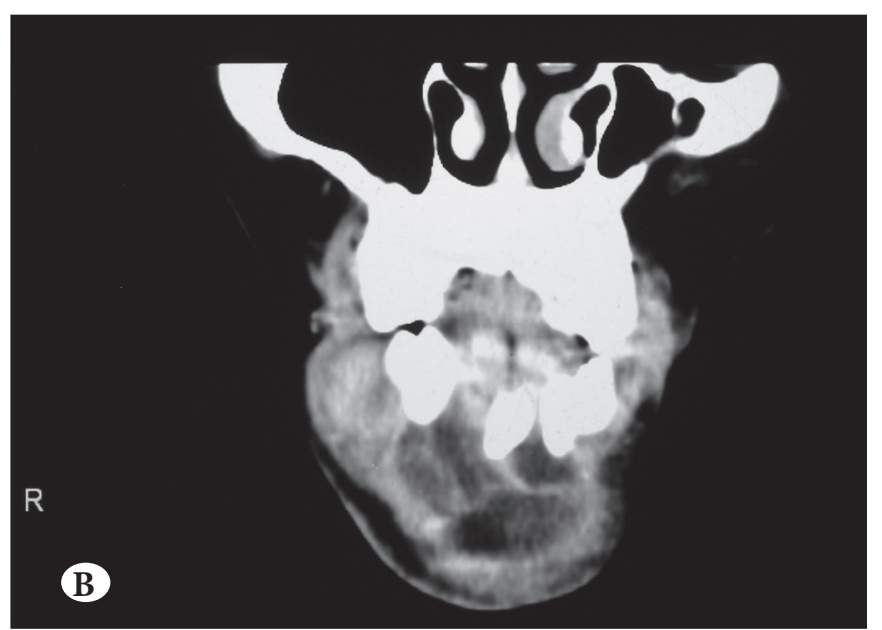

Figure 2: A) Computerized tomographic (CT) axial image of the lesion showing irregular destruction of the anterior mandibular bone. B) CT shows mesio-distal extension of the lesion in the mandibular region. 


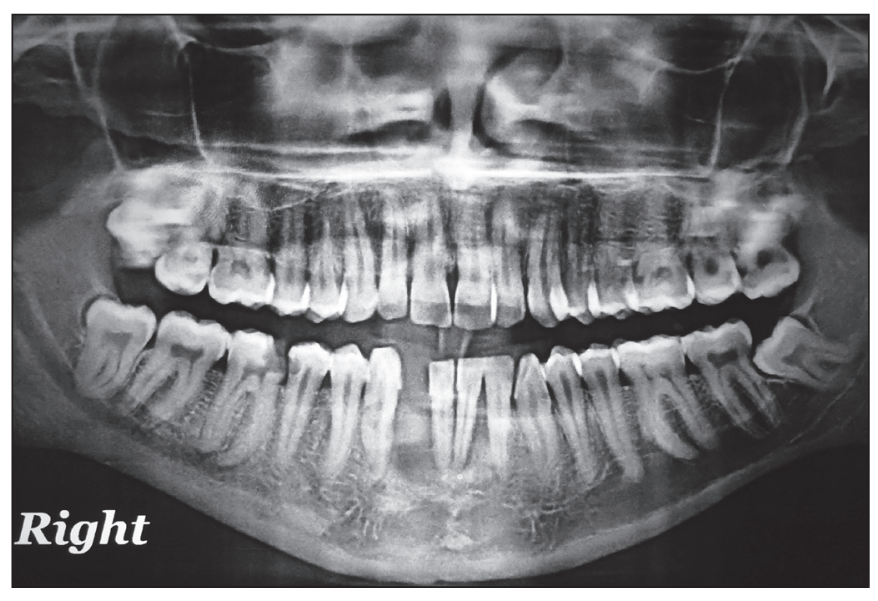

Figure 3: Orthopantomograph image shows loss of right mandibular lateral incisor and loosening of adjacent teeth.

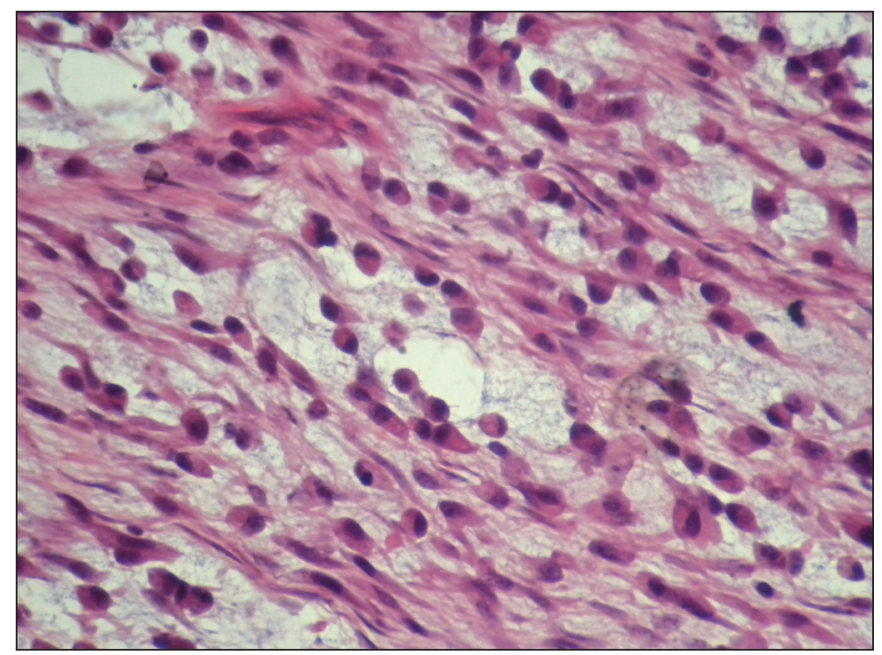

Figure 4: Sections showing round undifferentiated cells with hyperchromatic nuclei and myxoid area (H\&E; x400).

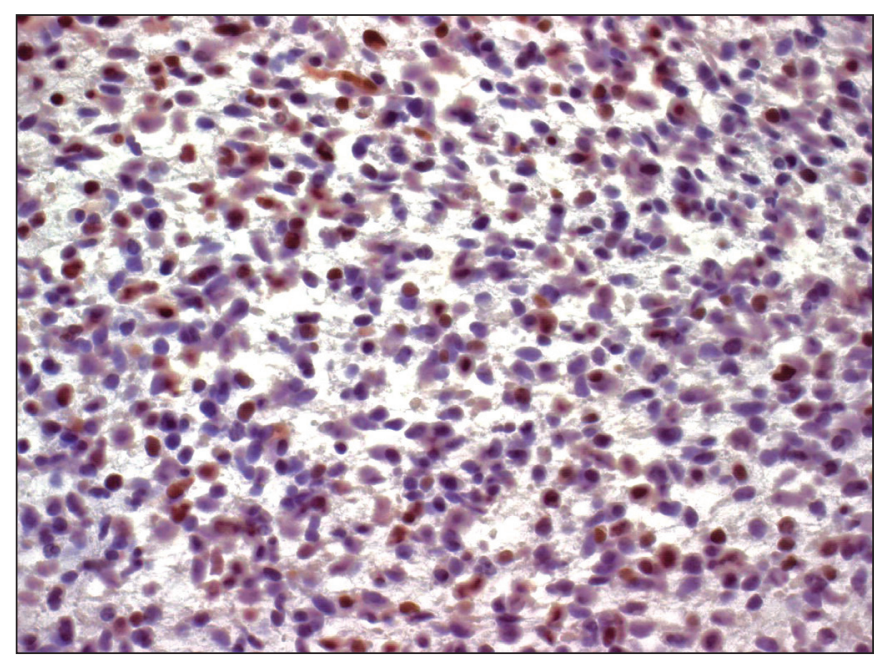

Figure 6: Positive immunohistochemical staining for myogenin (Myogenin; x100). vincristine, ifosfamide and actinomycin $\mathrm{D}$ regime. After three cycles of chemotherapy in 16 weeks the patient was followed with radiotherapy, which was administered for four weeks in once daily fractions of $1.8 \mathrm{~Gy}$. To date of this report, more than 6 months since diagnosis and treatment, he has no evidence of the disease.

\section{DISCUSSION}

RMS is a rare malignant lesion, more common in children and with a peak age of incidence between two to six years $(1,2,7)$. The reported patient was 36 years of age and it is very rare to see RMS at this age.

In the presented case, gingiva and alveolar mucosa of the right body of the mandible and anterior portion of the left

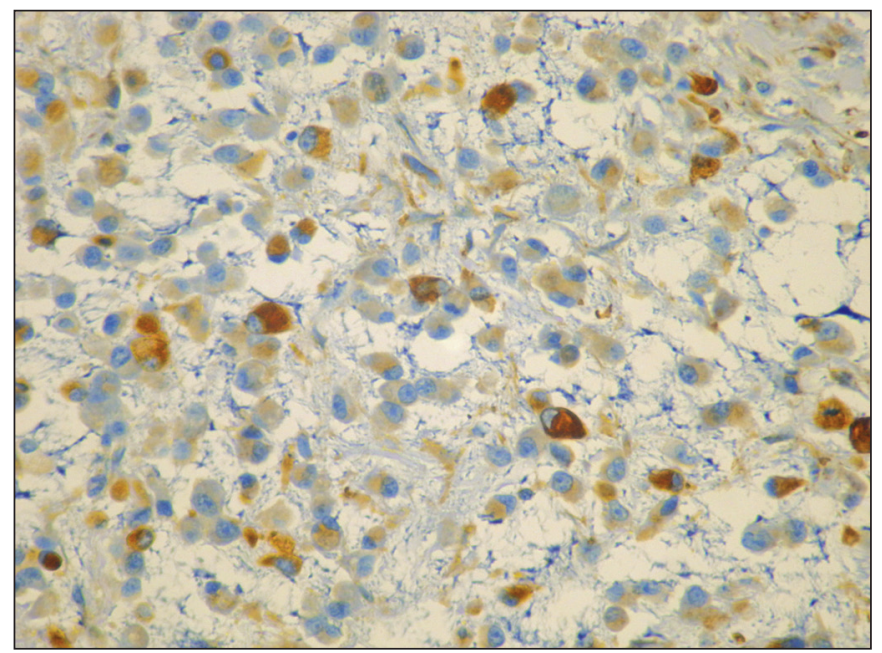

Figure 5: Positive immunohistochemical staining for desmin (Desmin; x400).

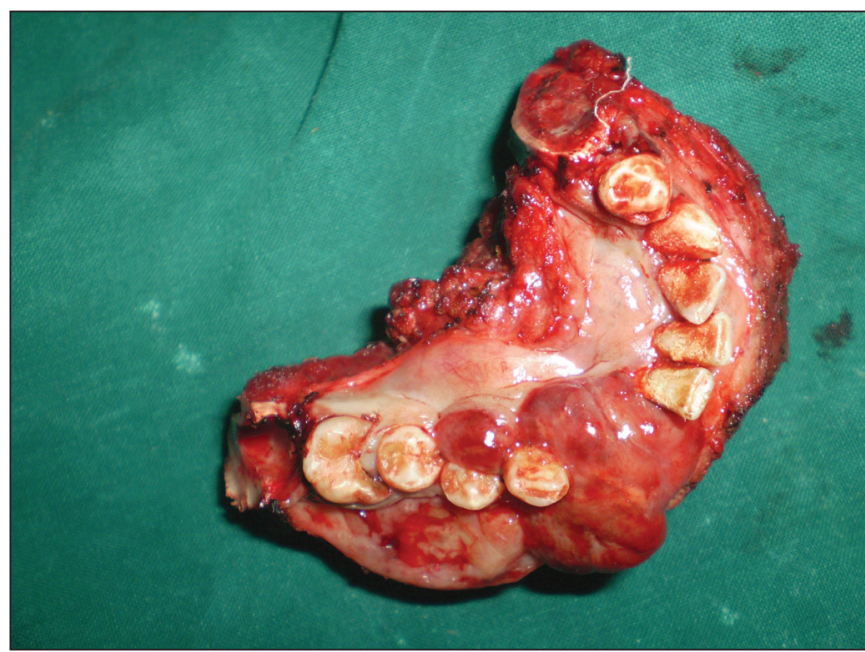

Figure 7: Tissue specimen after complete excision of the lesion. 
mandible were involved. Only a few cases of gingival RMS have been published (13). The present report adds to the literature of adult gingival RMS.

Clinical presentation of RMS is variable and influenced by site, age and the presence or absence of distant metastases. In general the primary lesion is a non-tender mass. The head and neck lesion may cause impairment of hearing, vision, speech, and swallowing, and respiratory symptoms may develop (14). The clinical features noted in the present case were facial asymmetry and obliteration of the labial and buccal vestibule due to the painless mass.

RMS is very rare in adults so the data on clinical presentation is inadequate. A number of studies have described that these tumors are more aggressive in adults compared to children and adolescents $(9,11,15)$. This case presented as a rapid recurrence and growth of lesion due to inadequate surgery.

Radiological examination of the lesion may reveal the size and extension of the lesion and extent of bone destruction (16). Through computerized tomography and panoramic radiography, we could determine that the lesion affected the body of the mandible with missing and loosening of teeth.

Horn and Enterline classified RMS histologically in four subtypes: embryonal, botryoid, alveolar, and pleomorphic. Botryoid RMS abuts an epithelial surface, with condensation of tumor cells in the immediate subepithelial zone. The alveolar variant has aggregates of round to oval neoplastic cells, separated by irregularly shaped fibrous trabeculae forming ill-defined alveolar spaces. The pleomorphic or classical variant is the adult type seen in adults over 40 years of age (12). The histopathological appearance of this case was of the embryonal subtype. Embryonal RMS has a favorable prognosis when compared to the other subtypes (17).

Immunohistochemically, cytoplasm-specific markers for RMS are myoglobin, desmin, muscle-specific actin while nucleus-specific markers are Myo D and myogenin. Desmin and muscle-specific actin are the most accepted makers and are used commonly in the diagnosis of RMS. Muscle transcription factors Myo D and myogenin are the most sensitive markers for immunohistochemical diagnosis of RMS. Both of these markers are expressed at high levels in RMS, even when cells are showing poor differentiation (12). In the presented case, we used a panel of immunohistochemical markers and found positive expression of desmin and myogenin.

RMS in adults is an aggressive tumor and has a higher incidence of recurrence. The best possible clinical outcome is therefore achieved via a multimodal approach. Sophisticated surgical techniques with reconstruction are used as the primary modality (9). RMS is a radiocurable lesion but results in radiation-induced secondary tumors (3). In addition, multiagent chemotherapy, including vincristine, adriamycin, cyclophosphamide, and actinomycin D reduces micro metastases and malignant cell population, thus favoring long-term survival with fewer complications (18). Due to the high recurrence rate and association with distant metastases of RMS, a high-quality treatment plan is required.

Sarcomas are extremely rare in the oral cavity. However in our day-to-day practice we may come across the rarest of the lesions with an unusual clinical presentation. Therefore, each and every lesion of the oral cavity should be examined thoroughly and all diagnostic techniques such as radiography, histopathology and immunohistochemistry should be considered to achieve a correct diagnosis. Lesions on the gingiva and the alveolar area may be due to RMS or any other sarcomas and these pathologies should be considered in the differential diagnosis.

\section{REFERENCES}

1. Stuart A, Radhakrishnan J. Rhabdomyosarcoma. Indian J Pediatr. 2004;71:331-7.

2. Peters E, Cohen M, Altini M, Murray J. Rhabdomyosarcoma of the oral and paraoral region. Cancer. 1989;63:963-6.

3. Al-Khateeb T, Bataineh AB. Rhabdomyosarcoma of the oral and maxillofacial region in Jordanians: a retrospective analysis. Oral Surg Oral Med Oral Pathol Oral Radiol Endod. 2002;93:580-5.

4. Miller RW, Young JL Jr, Novakovic B. Childhood cancer. Cancer. 1995 (1 suppl);75:395-405.

5. Donaldson SS. Rhabdomyosarcoma: Contemporary status and future directions: The Lucy Wortham James Clinical Research Award. Arch Surg. 1989;124:1015-20.

6. Seth T, Kempert P. Embryonal rhabdomyosarcoma of lower lip. Indian Pediatr. 2004;41:858-9.

7. Ries LAG, Harkins D, Krapcho M, Mariotto A, Miller BA, Feuer EJ, Clegg L, Eisner MP, Horner MJ, Howlader N, Hayat M, Hankey BF, Edwards BK editors. SEER Cancer Statistics Review, 1975-2003, National Cancer Institute. Bethesda, MD, http://seer. cancer.gov/csr/1975_2003/, based on November 2005 SEER data submission, posted to the SEER web site, 2006.

8. Stiller CA, McKinney PA, Bunch KJ, Bailey CC, Lewis IJ. Childhood cancer and ethnic group in Britain: A United Kingdom Children's Cancer Study Group (UKCCSG) study. Br J Cancer. 1991;64:543-8.

9. Ferrari A, Dileo P, Casanova M, Bertulli R, Meazza C, Gandola L, Navarria P, Collini P, Gronchi A, Olmi P, Fossati-Bellani F, Casali PG. Rhabdomyosarcoma in adults. A retrospective analysis of 171 patients treated at a single institution. Cancer. 2003;98: 571-80. 
10. Hawkins WG, Hoos A, Antonescu CR, Urist MJ, Leung DH, Gold JS, Woodruff JM, Lewis JJ, Brennan MF. Clinicopathological analysis of patients with adult rhabdomyosarcoma. Cancer. 2001; 91:794-803.

11. Little DJ, Ballo MT,Zagars GK, Pisters PW, Patel SR, El-Naggar AK, Garden AS, Benjamin RS. Adult rhabdomyosarcoma: Outcome following multimodality treatment. Cancer. 2002;95:377-88.

12. Parham DM. The pathologic classification of rhabdomyosarcomas and correlations with molecular studies. Mod Pathol. 2001;14: 506-14.

13. Chi AC, Barnes JD, Budnick S, Agresta SV, Neville B. Rhabdomyosarcoma of the maxillary gingiva. J Periodontol. 2007;78:1839-45
14. Dagher R, Helman L. Rhabdomyosarcoma: An overview, Oncologist. 1999; 4: 34-44.

15. Fernando Val-bernal J, Fernandez N, Gomez-Roman JJ. Spindle cell rhabdomyosarcoma in adults: A case report and literature review. Pathol Res Pract. 2000;196:67-72.

16. Maurer HM, Beltangady M, Gehan EA, Crist W, Hammond D, Hays DM, Heyn R, Lawrence W, Newton W, Ortega J. The Intergroup Rhabdomyosarcoma study-1. A final report. Cancer. 1988;61:209-20.

17. Solar AA, Jordan RCK. Soft tissue tumors and common metastases of the oral cavity. Periodontol 2000. 2011;57:177-97.

18. Simon JH, Paulino AC, Smith RB, Buatti JM. Prognostic factors in head and neck rhabdomyosarcoma. Head and Neck. 2002;24: 468-73. 